\title{
UPAYA PENINGKATAN KEMANDIRIAN MASYARAKAT MELALUI PEMBENTUKAN TIM PENGGERAK DESA SEHAT PENYAKIT TIDAK MENULAR DI KOTA TASIKMALAYA
}

\section{EFFORTS TO INCREASE COMMUNITY INDEPENDENCE THROUGH THE ESTABLISHMENT OF A HEALTHY VILLAGE MOVEMENT TEAM NONCOMMUNICABLE DISEASES (NCDS) IN THE CITY OF TASIKMALAYA}

\author{
Ida Sugiarti ${ }^{1}$, Iwan Soemantri ${ }^{1}$, Yanti Cahyati $^{1}$, Ida Rosdiana ${ }^{1}$, Ai Cahyati ${ }^{1}$, \\ Arief Tarmansyah Iman ${ }^{1}$, Tri Kusuma Agung Puruhita ${ }^{2}$ \\ ${ }^{1}$ Poltekkes Kemenkes Tasikmalaya \\ ${ }^{2}$ Poltekkes Kemenkes Semarang \\ *Email: ida.sugiarti@dosen.poltekkestasikmalaya.ac.id \\ (Diterima 08-09-2021; Disetujui 24-09-2021)
}

\begin{abstract}
ABSTRAK
Penambahan jumlah kasus Covid-19 berlangsung cepat, terutama gejala muncul pada pasien dengan comorbid yang mengakibatkan kematian. Salah satu comorbid yaitu Penyakit Tidak menular (PTM), diantaranya DM dan Hipertensi. Tingginya kasus PTM, membutuhkan perhatian dan identifikasi sedini mungkin serta penanganan segera agar tidak berakibat fatal. Pemerintah memiliki sumber daya yang terbatas dalam pengelolaan pelayanan kesehatan. Situasi pandemi Covid-19 juga membutuhkan perhatian khusus dan sumber daya yang tidak sedikit. Oleh karena itu, pentingnya melibatkan partisipasi masyarakat untuk terlibat terutama dalam pencegahan dan deteksi dini melalui pembentukan Tim Penggerak PTM. Metode yang digunakan berupa pelatihan dan pembentukan tim penggerak PTM yang didukung dengan aplikasi Lembur Sehat PTM. Hasil pengabdian kepada masyarakat terdapat peningkatan pengetahuan dari kader dan tim penggerak setelah pelatihan. Rata-rata nilai pre test pada tim penggerak wilayah Tawang yaitu 72,67 ; sedangkan rata-rata nilai post test yaitu 94,67. Rata-rata nilai pre test pada tim penggerak wilayah Cibeureum yaitu 63,64; sedangkan rata-rata nilai post test yaitu 90,36. Hasil monitoring dan observasi menunjukkan kader melakukan pendataan berupa pengukuran gula darah dan tensi serta mengisi data di aplikasi Lembur Sehat PTM. Jumlah kader yang mengikuti pelatihan sebanyak 60 kader dan karang taruna. Hasil observasi pada aplikasi tercatat 600 data masyarakat yang sudah dientry. Hasil pengukuran menjadi data bagi Puskesmas setempat dan akan ditindaklanjuti. Data juga dilaporkan ke Dinas Kesehatan Kota Tasikmalaya.
\end{abstract}

Kata kunci: PTM, Tim Penggerak, Aplikasi Lembur Sehat

\section{ABSTRACT}

The increase in the number of Covid-19 cases is fast, especially the symptoms that appear in patients with comorbidities that result in death. One of the comorbidities is Non-Communicable Diseases (NCDS), including DM and Hypertension. The high number of NCDS cases requires attention and knowledge about the possibility and immediate treatment so that it does not result in fatalities. The government has limited resources in the management of health services. Therefore it is important to involve community participation to be involved in early prevention activities through the formation of a NCDS Mobilization Team. The method used is in the form of training and formation of a NCDS mobilitation team supported by healthy overtime applications for NCDS drivers. The results of community service increase the knowledge of cadres and driving teams, after training. The average pre-test score for the Tawang area was 72.67, while the posttest average was 94.67. Cibeureum was 63.64 while the post-test average was 90.36. The results of monitoring and observation show that the cadres collect data in the form of measuring blood sugar and blood pressure and fill in the data in the Healthy Overtime Application for NCDS. The number of cadres who participated in the training was 60 cadres and youth organizations. The results of observations in the application recorded 600 community data that had been entered. The measurement results become data for the local Community Health Center and will be followed up. The data is also reported to the Tasikmalaya City Health Office.

Keywords: Non-Communicable Diseases, Mobilization Team, Healthy Overtime Application 
Upaya Peningkatan Kemandirian Masyarakat Melalui Pembentukan Tim Penggerak Desa Sehat Penyakit Tidak Menular di Kota Tasikmalaya

Ida Sugiarti, Iwan Soemantri, Yanti Cahyati, Ida Rosdiana, Ai Cahyati, Arief Tarmansyah Iman, Tri Kusuma Agung Puruhita

\section{PENDAHULUAN}

Dunia saat ini sedang dilanda pandemi Covid-19. Jumlah total kasus pasien yang terjangkit virus corona di Indonesia mencapai 4.116.890 (positif), sembuh (3.813.643), dan meninggal (134.930) per tanggal 3 September 2021 (https://covid19.go.id/ 2021). Dinas Kesehatan Kota Tasikmalaya melaporkan per tanggal 4 September 2021 angka positif Covid-19 yaitu 9.772 (terkonfirmasi), 9.069 (sembuh), dan 365 (meninggal) (https://pikobar.jabarprov.go.id/distribution-case 2021). Daerah dengan jumlah kasus yang banyak diantaranya adalah wilayah kerja Puskesmas Tawang dan Puskesmas Cibeureum (BPBD, 2020). Penambahan jumlah kasus Covid-19 berlangsung cepat, terutama gejala muncul pada pasien dengan comorbid yang mengakibatkan kematian. Salah satu comorbid yaitu Penyakit Tidak menular (PTM), diantaranya diabetes melitus (DM) dan hipertensi. Kasus hipertensi di Kota Tasikmalaya tahun 2017 tercatat 11.884 atau 8,30\% (Dinas Kesehatan Provinsi Jawa Barat, 2018). Kasus DM tahun 2018 sebanyak 2.135 kasus dan meningkat tajam tahun 2019 menjadi 4.172 kasus (Dinas Kesehatan Kota Tasikmalaya, 2017).

PTM merupakan penyebab kematian terbanyak di seluruh dunia (Sommer et al., 2015; World Health Organization 2014). Sejumlah 41 juta orang meninggal akibat PTM setiap tahunnya (WHO 2021; World Health Organization 2014). Jumlah ini setara dengan $71 \%$ dari seluruh kematian secara global (WHO 2021). Pada tahun 2016, sekitar 71 persen penyebab kematian di dunia adalah PTM. Tahun 2018, sekitar 80\% kematian terjadi di negara berpenghasilan menengah dan rendah, 73\% kematian saat ini disebabkan oleh PTM (Direktorat Jenderal Pencegahan dan Pengendalian Penyakit, 2019). Riskesdas 2018 menunjukkan prevalensi PTM mengalami kenaikan dibandingkan dengan Riskesdas 2013, antara lain kanker, stroke, penyakit ginjal kronis, DM dan hipertensi. Berdasarkan pemeriksaan gula darah, DM naik dari 6,9\% menjadi 8,5\%; dan hipertensi naik dari $25,8 \%$ menjadi 34,1\%. Kenaikan prevalensi ini berhubungan dengan status sosial ekonomi dan pola hidup, antara lain merokok, konsumsi minuman beralkohol, aktivitas fisik, serta diet (Allen et al. 2017).

Tingginya kasus PTM membutuhkan perhatian dan identifikasi sedini mungkin serta penanganan segera agar tidak berakibat fatal. Pemerintah, khususnya dinas kesehatan setempat dan puskesmas, memiliki sumber daya yang terbatas dalam pengelolaan pelayanan kesehatan. Situasi pandemi covid-19 juga membutuhkan perhatian khusus dan sumber daya yang tidak sedikit. Oleh karena itu, pentingnya melibatkan partisipasi masyarakat untuk terlibat terutama dalam pencegahan dan deteksi dini. Poltekkes 
Kemenkes Tasikmalaya sebagai bagian dari Kementerian Kesehatan memiliki kewajiban untuk ikut terlibat dalam pengendalian PTM, salah satunya yaitu dengan mengadakan kegiatan pengabdian kepada masyarakat sekaligus mengimplementasikan salah satu dari hasil penelitian yang telah dilakukan tentang PTM; Effect of Progressive Muscle Relaxation (PMR) on Blood Pressure among Patients with Hypertension (Rosdiana and Cahyati, 2019).

Penggunaan teknologi informasi dan komunikasi (TIK) seperti eHealth dan mHealth sangat penting untuk dicapai dalam upaya memperluas cakupan kesehatan universal (WHO, 2015). Adanya penetrasi telepon seluler baru-baru ini telah menghasilkan peningkatan adopsi mHealth service untuk kontrol dan perawatan PTM di negara-negara berpenghasilan tinggi. Meskipun di negara berpenghasilan rendah dan menengah bidang mHealth masih dalam masa pertumbuhan, namun dapat muncul sebagai alat vital dalam upaya pencegahan faktor risiko yang terkait PTM di tahun-tahun mendatang (Hussein, Harun, and Oon, 2016; Allen et al. 2017). Dengan mengaktifkan sumber daya berbasis seluler teknologi kesehatan, diharapkan dapat membantu memperkuat respons sistem kesehatan terhadap PTM dengan menawarkan cara-cara yang fleksibel untuk masyarakat dan profesional kesehatan dalam menerima dan memberikan layanan kesehatan (Feroz, Kadir, and Saleem, 2018). Ketersediaan gadget yang tersebar luas telah menimbulkan minat yang besar pada mHealth (kesehatan seluler). Penggunaan gadget berupa telepon seluler dapat membantu masyarakat menerima informasi dan pembinaan untuk mendukung perawatan diri. mHealth memberikan prospek peningkatan jangkauan tenaga kesehatan dalam memberikan layanan kesehatan yang efisien dan terjangkau untuk populasi yang luas dalam upaya pencegahan primer dan sekunder untuk beragam tujuan (Feroz, Kadir, and Saleem, 2018; Nguyen, 2019).

\section{BAHANDAN METODE}

Metode yang digunakan berupa pelatihan dan pembentukan tim penggerak PTM yang didukung dengan aplikasi Lembur Sehat PTM. Aplikasi yang digunakan merupakan hasil kerjasama dengan dosen UGM. Kegiatan dilaksanakan melalui beberapa rangkaian kegiatan yaitu menciptakan Aplikasi "Lembur Sehat Bebas PTM" yang berisi tentang data base warga terkait adanya PTM (Hipertensi dan DM) yang merupakan penyakit Comorbid Covid-19, pemantauan surveilance, kewaspadaan dini/early warning apabila ada hasil pemeriksaan terkait gula darah, hipertensi dan imt pribadi, pencegahan (diet, aktifitas dan latihan, senam diabetes), dan perawatan mandiri (latihan manajemen relaksasi Benson, 
Upaya Peningkatan Kemandirian Masyarakat Melalui Pembentukan Tim Penggerak Desa Sehat Penyakit Tidak Menular di Kota Tasikmalaya

Ida Sugiarti, Iwan Soemantri, Yanti Cahyati, Ida Rosdiana, Ai Cahyati, Arief Tarmansyah Iman, Tri Kusuma Agung Puruhita

manajemen relaksasi PMR/Progresive Muscle Relaxation. Selanjutnya, dilakukan pembentukan Tim Penggerak Desa Sehat PTM di wilayah kerja Puskesmas Tawang dan Cibeureum dengan jumlah peserta masing-masing 30 orang terdiri atas kader dan karang taruna. Pelatihan diselenggarakan dua hari, yaitu di tanggal 03-04 Agustus 2021 untuk peserta dari Cibeureum, dan tanggal 24-25 Agustus 2021 untuk peserta dari Tawang. Pelatihan hari pertama secara daring berupa materi terkait dan hari kedua berupa praktik pengukuran tekanan daran dan gula darah, serta tekhnik relaksasi. Tim penggerak dibekali dengan tensi digital dan alat pengkur gula darah, kemudian terlibat secara langsung dalam kegiatan deteksi atau surveilance kasus PTM. Tim penggerak mengentry data base ke aplikasi dan turun ke masyarakat. Kegiatan ini dilaksanakan dengan bantuan mahasiswa, dimonitoring oleh tim pengabmas, dan PJ PTM di Puskesmas, serta laporan ke Dinas Kesehatan Kota Tasikmalaya.

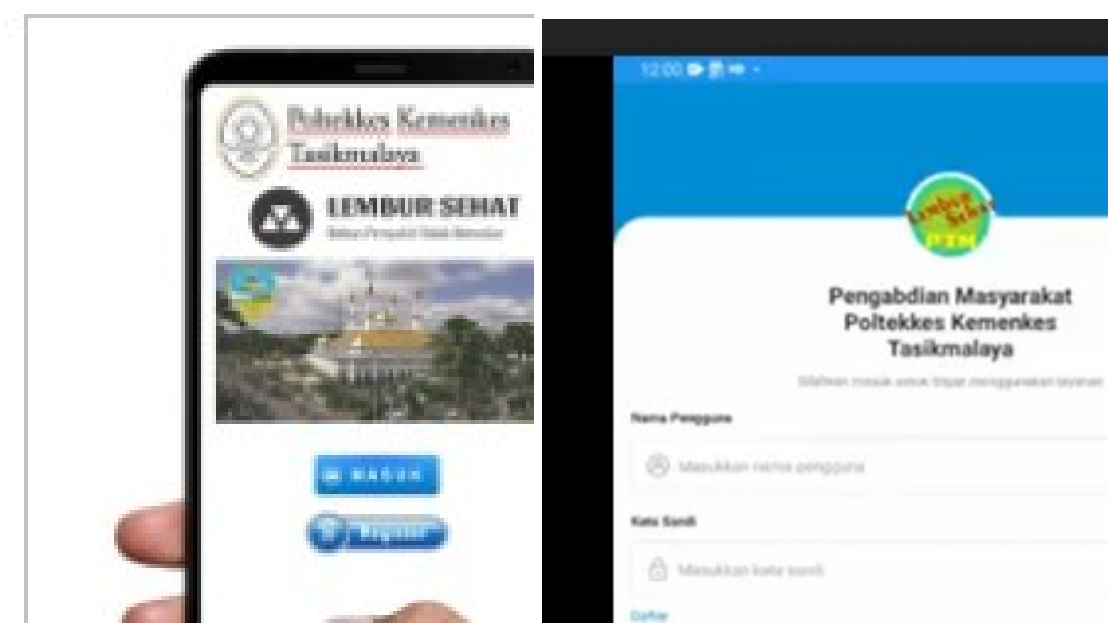

Gambar 1. Tampilan Aplikasi Lembur Sehat PTM

\section{HASIL DAN PEMBAHASAN}

Kegiatan pengabdian kepada masyarakat secara resmi dibuka oleh Sekda Kota Tasikmalaya dan dihadiri oleh Direktur Poltekkes Kemenkes Tasikmalaya, Direktur Poltekkes Kemenkes Semarang, Kepala Dinas Kesehatan, Kabid P2P, Kasie PTM dan jajarannya, Kepala Puskesmas dan PJ PTM. Pembukaan juga dihadiri oleh BPPSDM Kementerian Kesehatan sebagai pihak yang memberikan dana dan menaungi Poltekkes Kemenkes. Pelaksanaan kegiatan pembukaan secara daring dan luring di aula Poltekkes Kemenkes Tasikmalaya. Kegiatan diliput juga oleh Radar TV dan Kabar Priangan Online. Dapat disimak di laman berikut: 
https://kapol.id/akademisi-poltekes-tasik-semarang-ugm-bahu-membahu-antisipasikomorbid-covid-19/

https://www.youtube.com/watch?v=WLiV_J_X_84

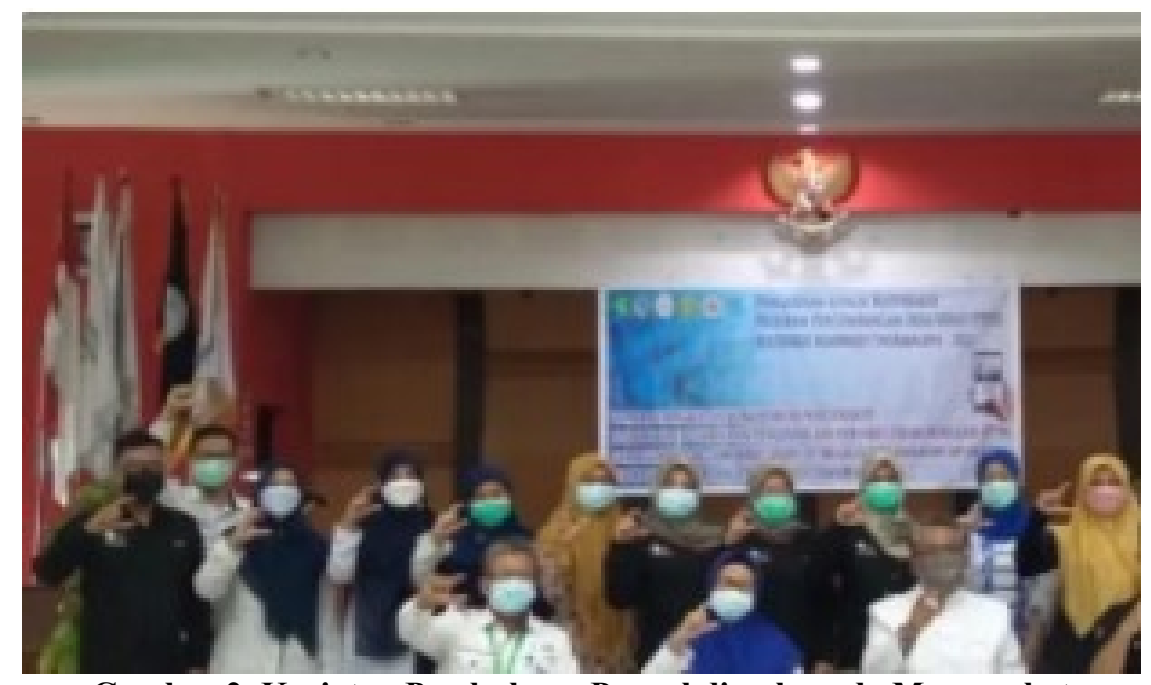

Gambar 2. Kegiatan Pembukaan Pengabdian kepada Masyarakat di Aula Poltekkes Kemenkes Tasikmalaya

Kegiatan diawali TOT (Taining of Trainer) terhadap mahasiswa dan PJ PTM secara daring dan luring untuk review materi dan aplikasi. Peserta mahasiswa dari jurusan keperawatan dan RMIK (Rekam Medis dan Informasi Kesehatan) sebanyak 10 orang.

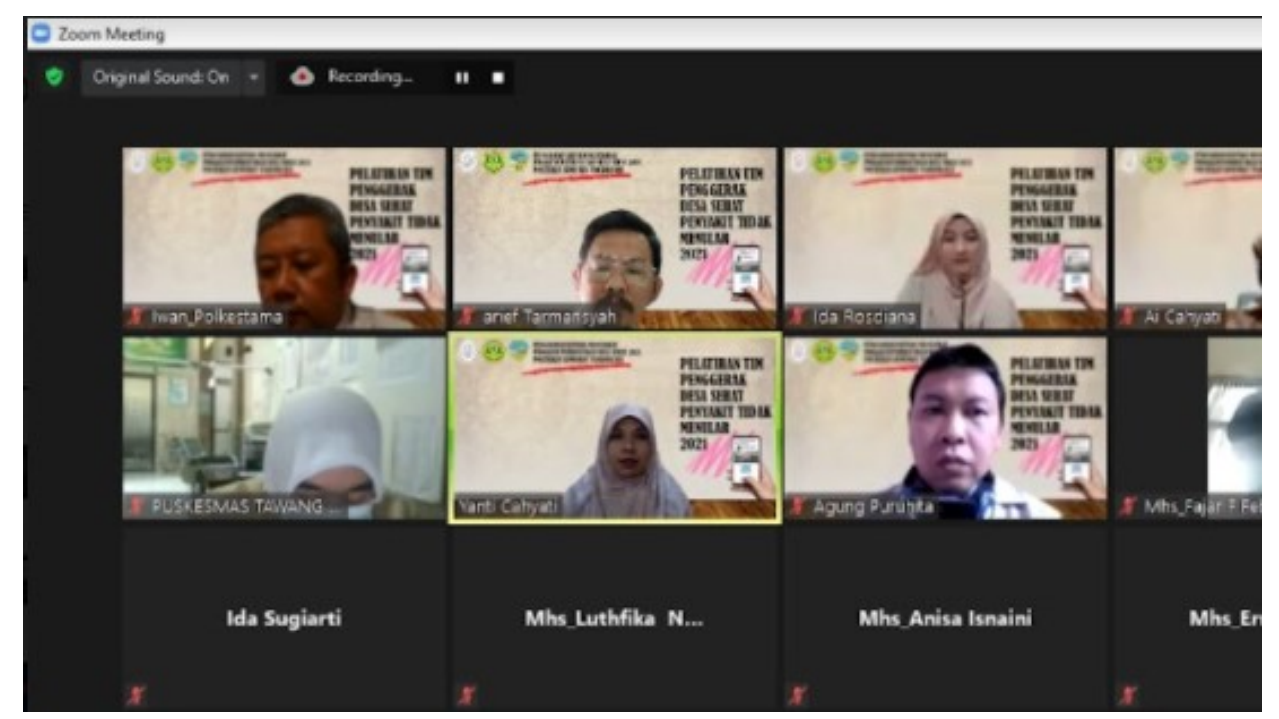

Gambar 3. TOT Materi secara daring dengan peserta mahasiswa 
Upaya Peningkatan Kemandirian Masyarakat Melalui Pembentukan Tim Penggerak Desa Sehat Penyakit Tidak Menular di Kota Tasikmalaya

Ida Sugiarti, Iwan Soemantri, Yanti Cahyati, Ida Rosdiana, Ai Cahyati, Arief Tarmansyah Iman, Tri Kusuma Agung Puruhita

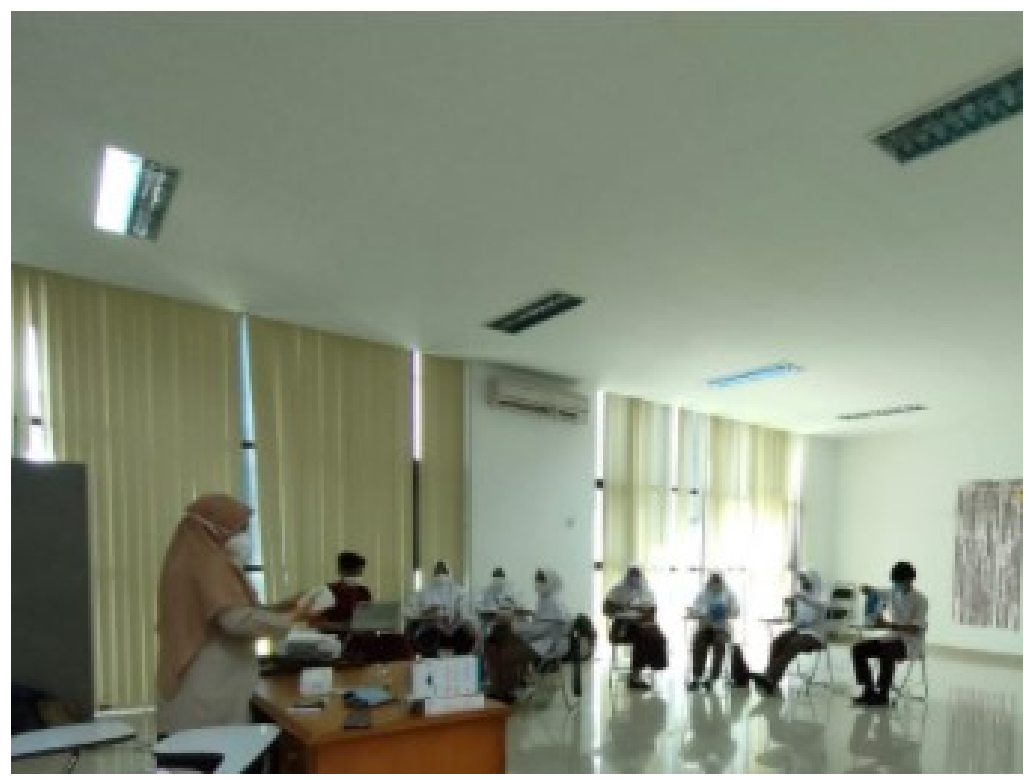

Gambar 4. TOT luring berupa pengukuran tensi dan gula darah

Pelatihan diawali dengan kegiatan pre test di hari pertama dan post test di hari kedua setelah kegiatan. Hasil pre test dan post tes tersaji pada Tabel 1.

Tabel 1. Distribusi Rata-Rata Score Pre test dan Post Test Pelatihan Tim Penggerak di wilayah Kerja Puskesmas Cibeureum Tahun 2021

\begin{tabular}{lccccc}
\hline score & Mean & SD & SE & p Value & n \\
& & & & & \\
\hline $\begin{array}{l}\text { Pre test } \\
\text { Post test }\end{array}$ & 63,64 & 14.8 & 3.73 & 0,0005 & 23 \\
\hline
\end{tabular}

Sumber: Analisis Data Primer (2021)

Tabel 1 menunjukkan rata-rata nilai pre test pada tim penggerak wilayah Cibeureum yaitu 63,64; sedangkan rata-rata nilai post test yaitu 90,36. Hasil uji statistik didapatkan $\mathrm{p}$ value 0,0005, maka dapat disimpulkan terdapat perbedaan yang signifikan antara nilai pre test dan post test pada kelompok tim penggerak wilayah Cibeureum.

Tabel 2 Distribusi Rata-Rata Score Pre test dan Post Test

Pelatihan Tim Penggerak di wilayah Kerja Puskesmas Tawang Tahun 2021

\begin{tabular}{lccccc}
\hline score & Mean & SD & SE & p Value & n \\
\hline Pre test & 72,67 & 12.8 & 2,05 & 0,0005 & 18 \\
Post test & 94,67 & 10.8 & & & \\
\hline \multicolumn{7}{c}{ Sumber: Analisis Data Primer (2021) } \\
\hline
\end{tabular}

Tabel 2 menunjukkan rata-rata nilai pre test pada tim penggerak wilayah Tawang yaitu 72,67; sedangkan rata-rata nilai post test yaitu 94,67. Hasil uji statistik didapatkan $\mathrm{p}$ value 0,0005 , maka dapat disimpulkan terdapat perbedaan yang signifikan antara nilai pre test dan post test pada kelompok tim penggerak wilayah Tawang. 


\begin{tabular}{ccccccc}
\multicolumn{7}{c}{$\begin{array}{c}\text { Tabel 3. Distribusi Perbedaan Rata-rata Nilai Pre test } \\
\text { pada Kelompok Tim Penggerak Cibeureum dan Tawang }\end{array}$} \\
\cline { 1 - 5 } Variabel & Kelompok & Mean & SD & SE & p Value & n \\
& & & & & & \\
\hline $\begin{array}{c}\text { Score Pre } \\
\text { Test }\end{array}$ & Cibeueum & 63,64 & 14,8 & 3.73 & 0,049 & 22 \\
\cline { 2 - 4 } & Tawang & 72,67 & 12,8 & 2,05 & & 18 \\
\hline \multicolumn{7}{c}{ Sumber: Analisis Data Primer (2021) }
\end{tabular}

Tabel 3 menunjukkan rata-rata skor nilai pre test pada kelompok tim penggerak Cibeureum adalah 63,64; sedangkan rata-rata rata-rata skor nilai pre test pada kelompok tim penggerak wilayah Tawang adalah 72,67. Hasil uji statistik didapatkan p-value 0,049, berarti pada alpa 5\% terlihat ada perbedaan yang siginifikan rata-rata skor nilai pre test pada kelompok tim penggerak wilayah Tawang dan Cibeureum.

\begin{tabular}{|c|c|c|c|c|c|c|}
\hline \multicolumn{7}{|c|}{$\begin{array}{l}\text { Tabel 4. Distribusi Perbedaan Rata-rata Nilai Post test } \\
\text { pada Kelompok Tim Penggerak Cibeureum dan Tawang }\end{array}$} \\
\hline Variabel & Kelompok & Mean & SD & SE & p Value & $\mathbf{n}$ \\
\hline \multirow{2}{*}{$\begin{array}{l}\text { Score Post } \\
\text { Test }\end{array}$} & Cibeueum & 90,36 & 14,4 & 3.73 & \multirow[t]{2}{*}{0,302} & 22 \\
\hline & Tawang & 94,67 & 10,8 & 2,05 & & 18 \\
\hline
\end{tabular}

Tabel 4 menunjukkan rata-rata skor nilai post test pada kelompok tim penggerak Cibeureum adalah 90,36; sedangkan rata-rata rata-rata skor nilai post test pada kelompok tim penggerak wilayah Tawang adalah 94,67. Hasil uji statistik didapatkan p-value 0,0302, berarti pada alpa 5\% terlihat tidak ada perbedaan yang siginifikan rata-rata score nilai pre test pada kelompok tim penggerak wilayah Tawang dan Cibeureum.

Pelatihan Tim Penggerak, di hari pertama dihadiri dan diberikan materi tentang PTM sebagai Comorbid Covid-19 oleh Kabid. P2P Dinas Kesehatan Kota Tasikmalaya. Selanjutnya pemberian materi oleh tim pengabdian kepada masyarakat berupa materi tentang Faktor comorbid Covid-19: Hipertensi, DM dan pengendaliannya, Gizi pada PTM, dan Dukungan Psikososial pada pasien dengan Comorbid Covid-19. 
Upaya Peningkatan Kemandirian Masyarakat Melalui Pembentukan Tim Penggerak Desa Sehat Penyakit Tidak Menular di Kota Tasikmalaya

Ida Sugiarti, Iwan Soemantri, Yanti Cahyati, Ida Rosdiana, Ai Cahyati, Arief Tarmansyah Iman, Tri Kusuma Agung Puruhita

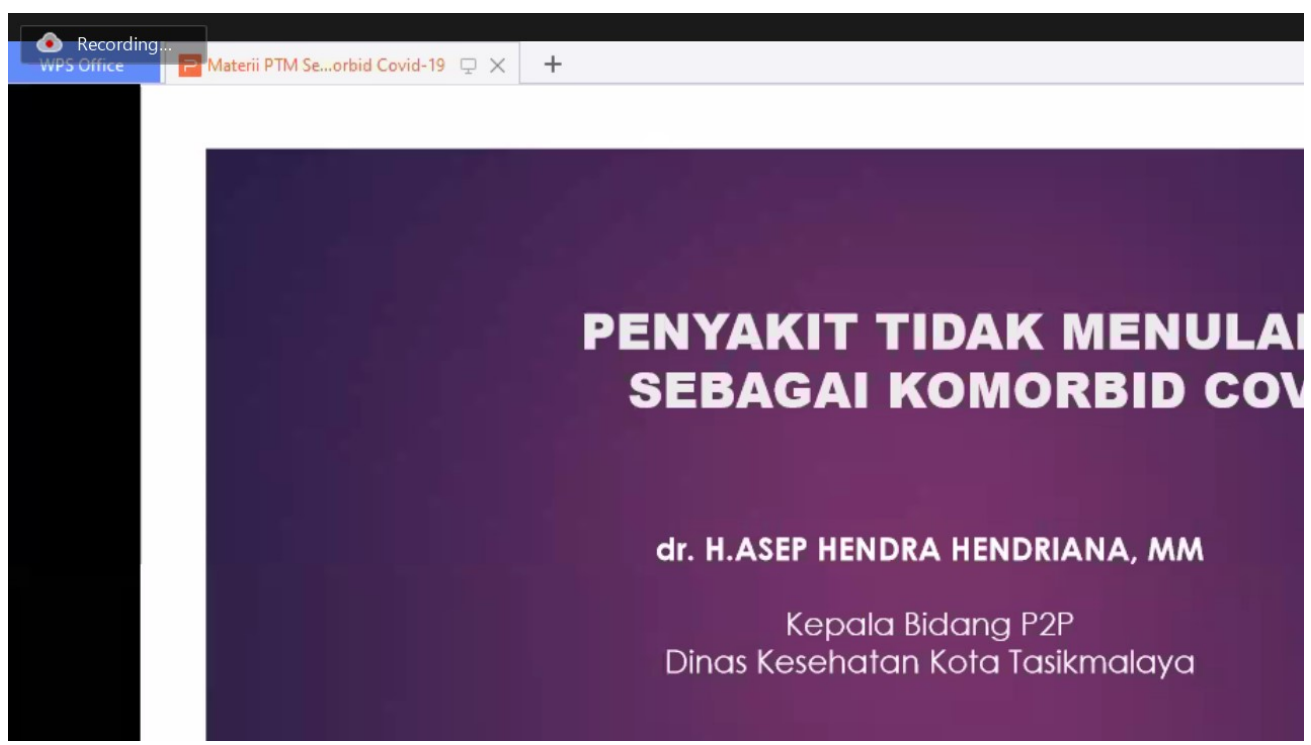

Gambar 5. Pelatihan Hari Pertama tanggal 3 Agustus 2021 Untuk Peserta Cibeureum

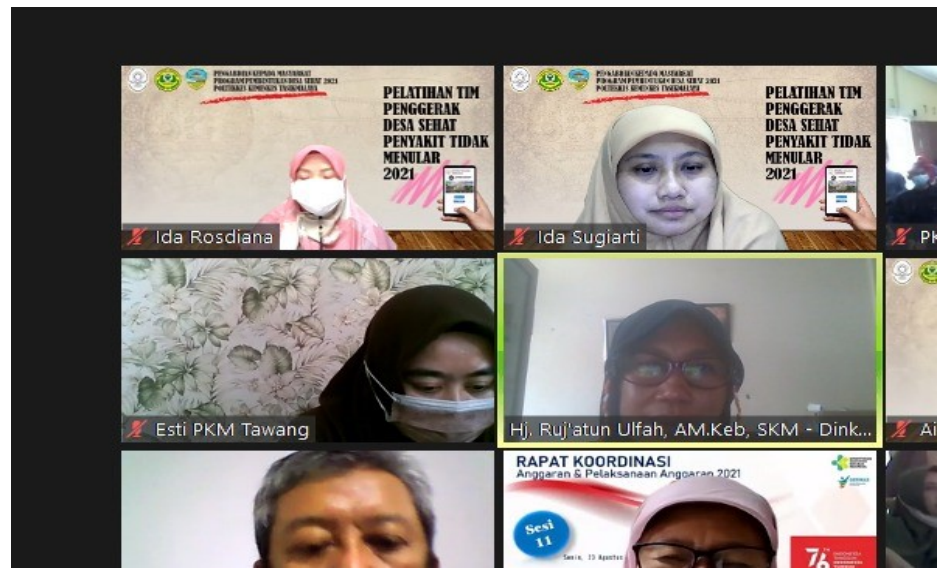

Gambar 6. Pelatihan Hari Pertama tanggal 24 Agustus 2021 Untuk Peserta Tawang

Selanjutnya di hari kedua materi dan praktik Tindakan Komplementer untuk pasien dengan PTM sebagai comorbid Covid-19, Pengenalan Aplikasi Lembur Sehat, dan Praktek Pemeriksaan gula darah dan tekanan darah. Kegiatan secara daring dan luring. Kegiatan praktik secara luring, kader dibagi menjadi 3 tempat supaya tidak terjadi kerumunan dan dibantu mahasiswa untuk praktik dengan tetap mempertahankan protokol kesehatan. Mahasiswa dan kader dilengkapi dengan masker dan hand schoon (sarung tangan). 


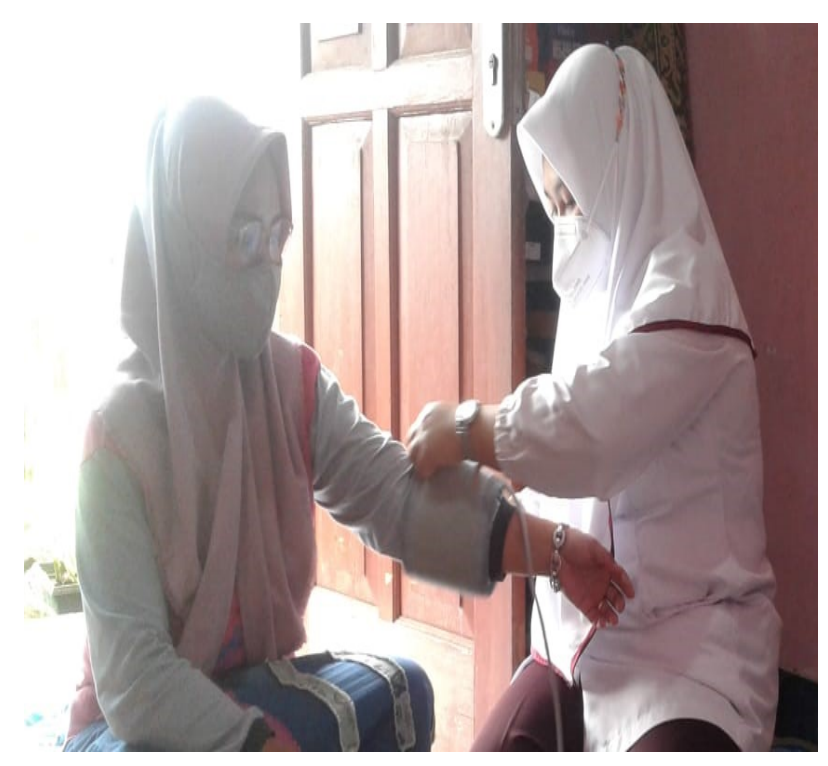

Gambar 7. Pelatihan Hari Kedua, Mahasiswa ke lokasi Kader

Setelah pelatihan kader dan karangtaruna melaksanakan kegiatan di masyarakat dengan didampingi PJ PTM.

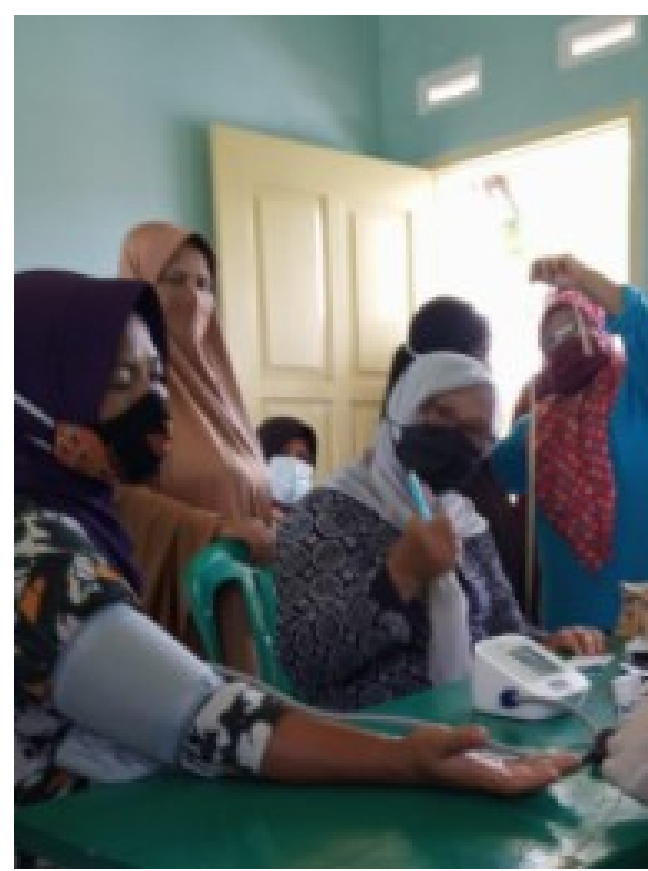

Gambar 8. Kegiatan Pelaksanaan Deteksi Dini PTM oleh Kader \& Karang Taruna 
Upaya Peningkatan Kemandirian Masyarakat Melalui Pembentukan Tim Penggerak Desa Sehat Penyakit Tidak Menular di Kota Tasikmalaya

Ida Sugiarti, Iwan Soemantri, Yanti Cahyati, Ida Rosdiana, Ai Cahyati, Arief Tarmansyah Iman, Tri Kusuma Agung Puruhita

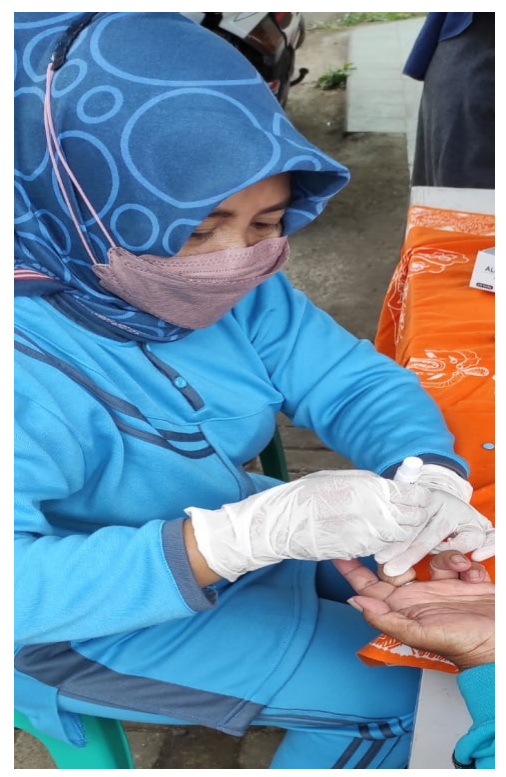

Gambar 9. Kegiatan Pelaksanaan Deteksi Dini PTM oleh Kader \& Karang Taruna

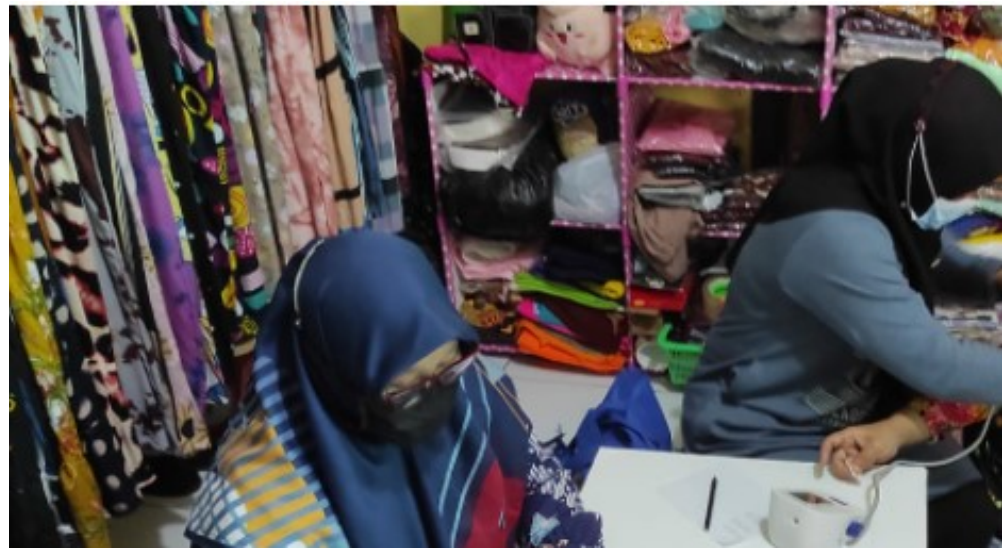

Gambar 10. Kegiatan Pelaksanaan Deteksi Dini PTM oleh Kader \& Karang Taruna

\section{KESIMPULAN DAN SARAN}

Kegiatan berjalan dengan baik sesuai perencanaan. Jumlah kader yang mengikuti pelatihan sebanyak 60 kader dan karang taruna. Hasil post test menunjukkan adanya peningkatan pengetahuan. Hasil monitoring di lapangan, dan dari aplikasi, kader sudah melaksanakan kegiatan pemeriksaan sesuai yang ditargetkan. Hasil observasi pada aplikasi tercatat 600 data masyarakat yang sudah dientry. Hasil pengukuran menjadi data bagi Puskesmas setempat dan akan ditindaklanjuti. Data juga dilaporkan ke Dinas Kesehatan Kota Tasikmalaya. 


\section{UCAPANTERIMAKASIH}

Ucapan terima kasih kami sampaikan kepada BPPSDM Kesehatan, Poltekkes Kemenkes Tasikmalaya atas dukungannya untuk terlaksanakanya kegiatan Pengabdian Kepada Masyarakat, Dinas Kesehatan Kota Tasikmalaya, Puskesmas Cibeureum dan Puskesmas Tawang atas fasilitasinya dalam rangkaian kegiatan pengabdian kepada masyarakat, Kader Kesehatan dan karang taruna yang telah berpartisipasi dalam kegiatan pengabdian kepada masyarakat.

\section{DAFTAR PUSTAKA}

Allen, Luke et al. 2017. "Socioeconomic Status and Non-Communicable Disease Behavioural Risk Factors in Low-Income and Lower-Middle-Income Countries: A Systematic Review." The Lancet. Global health 5(3): e277-89.

"BPBD." 2020.

Dinas Kesehatan Kota Tasikmalaya. 2017. "Perubahan Rencana Strategis Tahun 2017 2022."

Dinas Kesehatan Provinsi Jawa Barat. 2018. "Profil Kesehatan Tahun 2017."

Direktorat Jenderal Pencegahan dan Pengendalian Penyakit. 2019. "Buku Pedoman Penyakit Tidak Menular." Kementerian Kesehatan RI: 101. http://p2ptm.kemkes.go.id/uploads/VHcrbkVobjRzUDN3UCs4eUJ0dVBndz09/2019 /03/Buku_Pedoman_Manajemen_PTM.pdf.

Feroz, Anam, $\bar{M}$ Muhammad Masood Kadir, and Sarah Saleem. 2018. "Health Systems Readiness for Adopting Mhealth Interventions for Addressing Non-Communicable Diseases in Low- and Middle-Income Countries: A Current Debate." Global health action 11(1): 1496887.

“Https://Covid19.Go.Id/.” 2021.

"Https://Pikobar.Jabarprov.Go.Id/Distribution-Case." 2021.

Hussein, Zuhal, Amran Harun, and Siti Waringin Oon. 2016. "The Influence of the Smartphone User's Characteristics on the Intention to Use of M-Health." IJASOSInternational E-journal of Advances in Social Sciences 2: 598-602. http://ijasos.ocerintjournals.org/article/view/5000201166.

Nguyen, V. 2019. "Assessing the Feasibility and Accessibility of MHealth Application for Supporting the Prevention, Treatment, and Management of Non-Communicable Diseases in Hai ...." https://dash.harvard.edu/handle/1/40621349.

Rosdiana, Ida, and Yanti Cahyati. 2019. "Effect of Progressive Muscle Relaxation (Pmr) on Blood Pressure Among Patients With Hypertension." International Journal of Advancement in Life Sciences Research 2(1): 28-35.

Sommer, Isolde et al. 2015. "Socioeconomic Inequalities in Non-Communicable Diseases and Their Risk Factors: An Overview of Systematic Reviews." BMC Public Health 15(1): 914. https://doi.org/10.1186/s12889-015-2227-y.

WHO. 2015. "Health Systems Response to NCDs under Universal Access to Health and Universal Health Coverage." Forum of Key Stakeholders on NCDs. Advancing the NCD Agenda in the Caribbean.

- 2021. "Non Communicable Diseases." https://www.who.int/en/news- room/factsheets/detail/noncommunicable-diseases.

World Health Organization. 2014. "Global Status Report On Noncommunicable Diseases 2014." 